\title{
Use of a coupled soil-root-leaf model to optimise phosphate fertiliser use efficiency in barley
}

\author{
J. Heppell $\cdot$ S. Payvandi $\cdot$ P. Talboys $\cdot$ K. C. Zygalakis • \\ D. Langton • R. Sylvester-Bradley • A. C. Edwards • \\ R. Walker • P. Withers $\cdot$ D. L. Jones $\cdot$ T. Roose
}

Received: 28 October 2015 / Accepted: 1 April 2016/Published online: 14 April 2016

(C) The Author(s) 2016. This article is published with open access at Springerlink.com

\begin{abstract}
Aims Phosphorus (P) is an essential nutrient necessary for maintaining crop growth, however, it's often used inefficiently within agroecosystems, driving industry to find new ways to deliver $P$ to crops sustainably. We aim to combine traditional soil and crop measurements with climate-driven mathematical models, to give insight into optimising the timing and placement of fertiliser applications.

Methods The whole plant crop model combines an above-ground leaf model with an existing spatially explicit below-ground root-soil model to estimate plant $\mathrm{P}$ uptake and above ground dry mass. We let P-dependent photosynthesis estimate carbon (C)
\end{abstract}

Responsible Editor: Tim S. George.

\author{
J. Heppell · T. Roose \\ Faculty of Engineering and the Environment, University of \\ Southampton, Southampton SO17 1BJ, UK \\ J. Heppell $(\bowtie) \cdot$ K. C. Zygalakis · T. Roose \\ IFLS Crop Systems Engineering, University of Southampton, \\ Southampton SO17 1BJ, UK \\ e-mail: jph106@soton.ac.uk \\ S. Payvandi \\ Syngenta, Cambridge CB21 5XE, UK \\ P. Talboys $\cdot$ P. Withers $\cdot$ D. L. Jones \\ School of Environment, Natural Resources and Geography, \\ University of Bangor, Bangor 57 2UW, UK
}

mass, which in conjunction with temperature sets the root-growth-rate.

Results The addition of the leaf model achieved a better estimate of two sets of barley field trial data for plant $P$ uptake, compared with just the root-soil model alone. Furthermore, discrete fertiliser placement increases plant $\mathrm{P}$ uptake by up to $10 \%$ in comparison to incorporating fertiliser.

Conclusions By capturing essential plant processes we are able to accurately simulate $\mathrm{P}$ and $\mathrm{C}$ use and water and $\mathrm{P}$ movement during a cropping season. The powerful combination of mechanistic modelling and experimental data allows physiological processes to be quantified accurately and

K. C. Zygalakis

School of Mathematics, University of Southampton, Southampton SO17 1BJ, UK

D. Langton

Agrii, Cheltenham GL54 4LZ, UK

R. Sylvester-Bradley

ADAS Boxworth, Cambridge CB23 4NN, UK

A. C. Edwards · R. Walker

Crop \& Soil Systems, Scotland's Rural College, Aberdeen AB21 9YA, UK 
useful agricultural predictions for site specific locations to be made.

Keywords Mathematical modelling · Phosphate . Phosphorus · Fertiliser strategy · Barley field study . Above and below ground

\section{Introduction}

The world-wide production of food has increased due to the demands of an ever expanding global human population (Brown 2012). Due to the lack of land available for agricultural expansion, there is a need to increase crop yields sustainably by manipulating the existing environment in which crops are grown and breeding more resource efficient crops. Resource management for arable farming systems is critical to the survival of the human population and large amounts of money and time are needed to elicit the appropriate improvements (Conway and Barbier 1990).

Phosphorus $(\mathrm{P})$ is one of the essential nutrients required for plant growth and plays an important role in photosynthesis, respiration, and seed and fruit production. There have been repeated warnings concerning the use of phosphorus (normally occurring as phosphate in fertilisers) and its inevitable depletion (Déry and Anderson 2007; Cordell et al. 2009) warranting careful use of this finite resource (Vaccari 2009; Withers et al. 2015). Therefore we are faced with the hard task of increasing $\mathrm{P}$ use efficiency (using less $\mathrm{P}$ and at the same time increasing crop yields), which could be achieved by altering plant traits to reduce $\mathrm{P}$ demands of crops and / or increase recovery of added P, developing mechanical or chemical techniques to promote availability of added $\mathrm{P}$, and/or changing properties of the soil to enhance $\mathrm{P}$ capture by crop roots (Vance et al. 2003; Lynch 2007; Withers et al. 2014).

We are interested in how crops grow and survive in low $\mathrm{P}$ environments and how fertiliser and soil cultivation methods are influencing crop performance. A number of studies have considered the response of adding different amounts and rates of fertiliser P; in some soils large effects are seen whereas no effect is seen in others (Bolland and Baker 1998; Kuchenbuch and Buczko 2011; Valkama et al. 2011). There are many ways one could apply P to soils; for example incorporating (also known as broadcasting, involves an even spreading of $\mathrm{P}$ on top of the soil), placing (also known as banding, involves injecting $\mathrm{P}$ into the soil nearer the rooting zone either in row or between rows) or as a coating on seeds. Studies have shown that injecting fertiliser into the soil nearer to the root zone (placing) increases plant $\mathrm{P}$ uptake compared to incorporated P (Randall and Hoeft 1988; Lohry 1998; Owusu-Gyimah et al. 2013). In addition, studies have been conducted to estimate the differences in soil cultivation methods on plant $\mathrm{P}$ uptake; for example, conventional plough versus minimum tillage (also considering gene variation, George et al. 2011). The idea behind ploughing is to turn over or mix the top $25 \mathrm{~cm}$ of soil to loosen the soil for seeding, bury any existing crop residues or weeds, and to provide a good distribution of nutrients for the coming crop. This is in contrast to minimum tillage which enhances topsoil stability against erosion, retains moisture and reduces crop establishment costs, but segregates $\mathrm{P}$ content with depth and can leave $30 \%$ of crop residue on the soil surface.

Due to the rising cost of fertilisers and agricultural machinery, crop production has become a multiobjective optimisation problem to minimise multiple costs while trying to maximise the crop yield and environmental impact of fertilisers. This is a complex problem due to varying climatic conditions, an abundance of technological machines, and availability of more data concerning the states of fields than ever before. Precision agriculture is an emerging field involved with combining the newest technologies to the farming industry, ranging from unmanned drone maps of fields to computer-assisted tractors (Blackmore 2014). This new technology is enabling automated real time decision making, applying the most effective treatment to crops at the best time for the best price. Mathematical models, supported by experimental data, are needed to help predict best decisions in the short term, and also strategically, to optimise between possible future options. Whilst such models are not always commercially used, their potential capabilities are attractive, given that field-scale experiments are both costly and time-consuming, and integration and dissemination of their empirical results is challenging (Selmants and Hart 2010; Jeuffroy et al. 2012; Sylvester-Bradley 1991).

A plethora of models exist that describe the processes involved in plant growth and the behaviour of nutrients and water in the soil. Each model has its own unique assumptions and is generally targeted at specific scientific problems within the area of agriculture. For example, Greenwood et al. (2001) developed a dynamic 
model (PHOSMOD) for the effects of soil $\mathrm{P}$ and fertiliser $\mathrm{P}$ on crop growth, $\mathrm{P}$ uptake and soil $\mathrm{P}$ in arable cropping; Jones et al. (2003) describe a decision support system for agrotechnology transfer (DSSAT) which focuses on average plant-environment interactions; and Keating et al. (2003) review an agricultural production systems simulation (APSIM) developed in CISRO, Australia which deals with water, N, P, $\mathrm{pH}$, erosion and management issues. At the beginning of the 21st century, modelling 3D architectures of plant roots (RootBox, ROOTMAP, SimRoot, RootTyp, SPACSYS, R-SWMS) has become popular (Dunbabin et al. 2013). In addition, two research groups that model above ground 3D plant structures, Prunsinkiewicz Algorithmic Botany group at the University of Calgary and the Andrieu group (ADEL-wheat model), both use $\mathrm{L}$ systems to simulate the above ground structure of wheat plants. L systems, introduced by Lindenmayer in 1968, represent a string of production rules that are used to create geometric structures, ideal for plant development (Lindenmayer 1968). However all these models do not describe the root-soil interaction explicitly and do not fully integrate functions that occur above ground with ones that occur below ground. Therefore plants of the same genotype are represented alike and phenotypic differences cannot be observed. We hope to address some of these problems by creating a model that links the above and below ground processes in such a way that they rely on one another. Our whole crop model is based on a below ground plant-soil interaction model (Roose and Fowler 2004b; Heppell et al. 2015) coupled with an above ground leaf growth model based on the seminal work of Thornley (1995).

Here we describe a whole crop model that includes a below-ground root model and an above-ground leaf model and which is validated against experimental data on barley with a varying P fertiliser scenario analysis. The development of the model is seen as a step-change in our computational capability to help predict soil $\mathrm{P}$ supply, crop $\mathrm{P}$ uptake patterns and fertilizer requirements.

\section{Materials and methods}

Experimental data

Two barley field trial data sets are used, consisting of above ground dry mass and plant $\mathrm{P}$ uptake values at different growth stages (GS31, GS45 and GS91 for spring barley; GS39 and GS92 for winter barley). The experimental data includes different rates of $\mathrm{P}$ application $\left(0,5,10,20,30,60,90 \mathrm{~kg} \mathrm{P}^{-1}\right.$ for spring barley; $015,30,60,90,120 \mathrm{~kg} \mathrm{P}^{-1}$ for winter barley) and both sites were classified with an Olsen P index 1 soil (Defra 2010). The protocol for this is described in Heppell et al. (2015). In addition, we use the climate data, from the UK Met office Integrated Data Archive System (MIDAS), to accompany the spring barley (Inverurie, Scotland) and winter barley (Cambridge, England) data sets for the specific fields in the trial. The climate data consists of daily values for mean temperature $\left({ }^{\circ} \mathrm{C}\right)$, rainfall $(\mathrm{mm})$, wind speed $\left(\mathrm{m} \mathrm{s}^{-1}\right)$ and humidity (\%).

Modelling the whole crop

In this paper we extend a root-soil model (Roose and Fowler 2004b; Heppell et al. 2015) which estimates plant $\mathrm{P}$ uptake, with an above ground leaf model which estimates above ground dry mass (based on Thornley 1995), to produce a whole crop model. We first describe the root-soil model (hereafter called the root model), followed by the leaf model and then our coupling process to create a whole crop model.

Root and soil model

To model the root system we follow the same approach as described in Roose and Fowler (2004b) and Heppell et al. (2015) by modelling two orders of root branches only (main and first order branches). First order roots branch off the main order roots at a given density $\left(\psi_{1}\right)$, branching angle $(\theta)$, and each order of roots has a given maximum length and radius ( $L 0, L 1$ and $a, a_{1}$ for main and first order roots, respectively). As in Roose and Fowler (2004b) and Heppell et al. (2015) we let the root growth slow down as the root becomes longer. Following Heppell et al. (2015) we also let the root growth rate ( $r$ ) be dependent upon air temperature $T$, we detained from the MIDAS database,

$\frac{\partial l_{i}}{\partial t}=r(T(t))\left(1-\frac{l_{i}}{L_{i}}\right)$,

where $l_{i}$ is the current length of an order $i$ root and $L_{i}$ is the maximum length of an order $i$ root. 
The root-soil model is described by the following two equations for water saturation $(S)$ (Eq. 2) and P (Eq. 3) concentration (c) respectively,

$$
\begin{aligned}
& \phi \frac{\partial S}{\partial t}=\nabla \cdot\left[D_{0} D(S) \nabla S-K_{S} k(S) \hat{\boldsymbol{k}}\right]-F_{w}(S, z, t), \\
& \frac{\partial}{\partial t}[(b+\phi S) c]+\nabla \cdot[c \boldsymbol{u}] \\
& \quad=\nabla \cdot\left[D_{f}, \phi^{d}, S^{d}, \nabla, c\right]-F(c, z, t),
\end{aligned}
$$

where the water flux in the soil, $\boldsymbol{u}$, is given by Darcy's law,

$\boldsymbol{u}=-D_{0} D(S) \nabla S+K_{S} k(S) \hat{\boldsymbol{k}}$.

In the above equations $S$ is the relative water saturation given by $S=\phi_{1} / \phi$, $\phi_{1}$ is the volumetric water content, and $\phi$ is the porosity of the soil. $D_{0}\left(\mathrm{~cm}^{2}\right.$ day $\left.^{-1}\right)$ and $K_{S}\left(\mathrm{~cm} \mathrm{day}^{-1}\right)$ are the parameters for water 'diffusivity' and hydraulic conductivity, respectively (Van Genuchten 1980). $D(S)$ and $K(S)$ characterize reduction in water 'diffusivity' and hydraulic conductivity in response to the relative water saturation decrease, where the functional forms for partially saturated soil are given by Van Genuchten (1980). $\hat{\boldsymbol{k}}$ is the vector pointing vertically downwards from the soil surface and $F_{w}$ is the water uptake by the plant root system per unit volume of soil as given by Roose and Flower (2004a).

For the total P conservation (Eq. 3), $c$ is the P concentration in soil pore water, $b$ is the soil buffer power characterising the amount of $\mathrm{P}$ bound to the soil particle surfaces, $D_{f}$ is the $\mathrm{P}$ diffusivity in free water and $d$ is an impedance factor; $1 \leq d \leq 3$ (Barber 1984; Nye and Tinker 1977). $F(c, S, t)$ describes the rate of plant $\mathrm{P}$ uptake by a root branching structure (Roose et al. 2001). Both $F_{w}$ and $F$ are affected by the spatially and temporally evolving root structure. Water is only taken up by the main order roots and the small region of first order roots near the branch point while $\mathrm{P}$ is taken up by all roots; see Roose and Fowler (2004b) for details of the derivation. The equation for $F_{w}$ is given by,

$$
F_{W}=\frac{2 \pi a_{1} k_{r}+\left(2 \pi a_{1} k_{r} k_{z}\right)^{\frac{1}{2}} \psi_{1}(z)}{\pi\left(a+L_{1} \cos \theta\right)^{2}}\left[-p_{c} f(S)-p_{r}\right],
$$

where $\psi_{1}$ is the density of first order roots on the main order roots, $a_{1}$ is the first order root radius, $a$ is the main order root radius, $L_{1}$ is the maximum length of the first order branches, $\theta$ is the angle between the main root and the first order branches, $k_{r}$ is the root radial water conductivity parameter $\left(\mathrm{m} \mathrm{s}^{-1} \mathrm{~Pa}^{-1}\right), k_{z}$ is the root axial hydraulic conductivity calculated using Poiseuille law $\left(\mathrm{m}^{4} \mathrm{~Pa}^{-1} \mathrm{~s}^{-1}\right), p_{c}(\mathrm{~Pa})$ is a characteristic suction pressure determined from experimental data for different types of soil, $f(S)=\left(s^{-1 / m}-1\right)^{1-m}$, where $m$ is the Van Genuchten soil suction parameter (where $0<m<1$ ), and $p_{r}$ is the root internal xylem pressure $(\mathrm{Pa})$.

Root internal xylem pressure $\left(p_{r}\right)$ is calculated by balancing radial and axial fluid fluxes inside the root, i.e. after Roose and Flower (2004a) we have,

$2 \pi a k_{r}\left(-p_{c} f(S)-p_{r}\right)=-k_{z} \frac{\partial^{2} p_{r}}{\partial z^{2}}$,

with two boundary conditions; an impermeable root tip (Eq. 7) and a root internal pressure $(P)$ at the base of the zero order root (Eq. 8),

$\frac{\partial p_{r}}{\partial z}=0$ at $z=L$,

$p_{r}=P$ at $z=0$,

where $P$ is a function of temperature $(T)$, humidity $(H)$ and a base line pressure $\left(p_{r}^{0}\right)$ for fitting parameters $\lambda_{1}, \lambda_{2}$ and $\lambda_{3}$, (see Heppell et al. 2014 for the procedure to estimate them), i.e.

$P=\left(p_{r}^{0}+\lambda_{3}\right)+\lambda_{1} T+\lambda_{2} H$.

The rate of plant $\mathrm{P}$ uptake is given by,

$F(c, z, t)=\frac{F_{0}+F_{1}}{\pi\left(a+L_{1} \cos \theta\right)^{2}}$,

where $F_{0}$ and $F_{1}$ are the uptake rates for zero and first order roots; see Roose and Fowler (2004b) for derivation.

The boundary conditions to accompany Eqs. 1 and 2 include a soil surface boundary condition for water,

$-D_{o} D(S) \frac{\partial S}{\partial z}+K_{S} k(S)=W_{\operatorname{dim}}$ at $z=0$.

$W_{\text {dim }}$ (the flux of water into the soil) is dependent upon rainfall $(R)$, humidity $(H)$, temperature $(T)$, wind speed $(W S)$ and a constant $(E)$ which sets a base line flux i.e.

$W_{d i m}=\delta R+\alpha H+\beta T+\gamma W S+E$, 
for fitting parameters $\delta, \alpha, \beta$ and $\gamma$ (see Heppell et al. 2014 for how these values were estimated).

In addition, we have a zero flux boundary condition for the concentration of $\mathrm{P}(c)$ at the soil surface,

$-D_{f} \phi^{d} S^{d} \frac{\partial c}{\partial z}+W_{\text {dim }} c=0$ at $z=0$, for $t>0$.

We set a zero flux at the bottom of the soil $\left(l_{W}\right)$ for both $\mathrm{P}$ and water,

$-D_{o} D(S) \frac{\partial S}{\partial z}+K_{S} k(S)=0$ at $z=l_{W}$

$-D_{f} \phi^{d} S^{d} \frac{\partial c}{\partial z}=0$ at $z=l_{W}$

The initial state of $\mathrm{P}$ concentration and water saturation in the soil is given, where possible, by the initial soil data for the spring and winter barley experimental sites. A uniform water saturation profile is initially set at $S=0.3$ for the two experimental sites; however for the initial $\mathrm{P}$ concentration $\left(c_{0}(z)\right)$ we consider two different cases; (1) a uniform concentration and (2) an exponentially decaying concentration:

$$
\begin{aligned}
& \text { (1) } c_{0}(z)=c_{A} \quad \text { at } t=0, \forall z \\
& \text { (2) } c_{0}(z)=A_{1} e^{-B_{1} z} \text { at } t=0, \forall z \text { ' }
\end{aligned}
$$

where $c_{A}$ is set to $16 \mathrm{mg} \mathrm{P}^{-1}, A_{1}$ is the $\mathrm{P}$ concentration at the top of the soil, i.e. at the soil surface $\left(23 \mathrm{mg} \mathrm{P} \mathrm{L}^{-1}\right)$ and $B_{1}$ is the strength of the decay in the concentration of $\mathrm{P}(0.345)$. The initial $\mathrm{P}$ concentration values $\left(C_{A}, A_{1}\right.$ and $B_{1}$ ) come from a best fit to the data sets in Heppell et al. (2015) and are both classified as an Olsen P index 1 soil (Defra 2010). To reflect the different fertiliser scenarios being used at each field site a set amount of $\mathrm{P}(P 1)\left(0-120 \mathrm{~kg} \mathrm{P} \mathrm{ha}^{-1}\right)$ was either applied at the surface $(\mathrm{z}=0)$ (P broadcast) or at a set depth below the soil $\left(D_{1}\right)$ (P placement).

$$
\begin{array}{cccc}
c=c_{0}(z)+H(z), \\
\text { (broadcast) } & H(z)=P_{1} \text { at } t=0, & z=0 \\
\text { (placement) } & H(z)=P_{1} \text { at } t=0, & z=D_{1} \\
\text { (else (control)) } & H(z)=0 \quad \text { at } t=0, & \forall z
\end{array}
$$

With the soil P profile initialised (Eqs. 16 and 17) we are able to estimate (belowground only) the water and $\mathrm{P}$ concentrations in the soil by solving Eqs. 1-15, as in Heppell et al. 2014.

Leaf growth model

We have altered a compartmental model developed by Thornley (1995) to describe leaf mass (a proxy for above ground dry mass) $M_{L}(\mathrm{kgL})$, leaf C $M_{C}(\mathrm{kgC})$ and leaf $\mathrm{P} M_{P}(\mathrm{kgP})$ as well as the concentration of free $\mathrm{C}[C]=M_{C} / M_{L}\left(\mathrm{kgC} \mathrm{kgL}^{-1}\right)$ and free $\mathrm{P}[P]=M_{P} / M_{L}$ $\left(\mathrm{kgP} \mathrm{kgL}^{-1}\right)$ dynamics within the leaves. The leaf model takes into account non-linear dynamics of formation of leaf litter and leaf self-shading. Additionally we have made photosynthesis dependent upon $\mathrm{P}$ content in the plant (Foyer and Spencer 1986; Wissuwa et al. 2005) and we have altered the leaf growth term, $G_{s h}$, which was dependent on $[\mathrm{C}]$ and $[\mathrm{P}]$, to also depend upon air temperature $\left(A_{T}\right)$ for winter barley, but not for spring barley. We do not let air temperature affect spring barley as the growing season is much shorter compared to winter barley and it appeared not to be needed for a good fit to the experimental data. The governing equations are given below and are represented in a flow diagram on Fig. 1, i.e., we have

$$
\frac{\partial M_{L}}{\partial t}=\overbrace{G_{S h}}^{\text {Leaf growth rate }}-\overbrace{\frac{K_{\text {litt }}}{1+\frac{K_{\text {mlitt }}}{M_{L}}} M_{L}}^{\text {Leaf metabolism/litter }}
$$

Production of $\mathrm{C}$ from photosynthesis Use of $\mathrm{C}$ for $\mathrm{L}$ growth Output of $\mathrm{C}$ to phloem

$$
\begin{aligned}
& \frac{\partial M_{C}}{\partial t}=\overbrace{\varepsilon k_{1}[P]}-\overbrace{f_{c} G_{s h}}-\overbrace{\beta_{c}[C]} \text {, } \\
& \text { Use of P for L growth Input of P from xylem Output of } P \text { to phloem Use of P to produce C } \\
& \frac{\partial M_{P}}{\partial t}=\overbrace{-f_{p} G_{s h}}^{+}-\overbrace{F(c, z, t)}-\overbrace{\beta_{p}[P]}-\overbrace{k_{p} \varepsilon[P] k_{1}},
\end{aligned}
$$


where,

$G_{s h}=k_{G} M_{L}[C][P] \frac{A_{T}^{s_{1}}}{s_{2}^{s_{1}}+A_{T}^{s_{1}}}$,

$\varepsilon=\frac{k_{C} M_{L}}{\left(1+\frac{M_{L}}{k_{M}}\right)\left(1+\frac{[C]}{J_{C}}\right)}$,

where $k_{g}$ is the leaf growth rate, $K_{\text {litt }}$ is the litter rate, $K_{\text {mlitt }}$ is the litter Michaelis-Menten constant, $K_{C}$ is the photosynthesis rate, $k_{M}$ is the constant accounting for the leaf self-shading, $J_{c}$ is the $\mathrm{C}$ product inhibition constant, $f_{c}$ is the fraction of total $\mathrm{C}$ used for leaf growth, $f_{p}$ is the fraction of total $\mathrm{P}$ used for leaf growth, $k_{1}$ is the amount of $\mathrm{P}$ used for photosynthesis, $k_{\mathrm{p}} k_{1}$ is the $\mathrm{P}$ loss due to photosynthesis, $\beta_{c}$ is the rate of $\mathrm{C}$ output from the xylem to the phloem, $\beta_{p}$ is the rate of $\mathrm{P}$ output to the phloem, $F(c, z, t)$ is the rate of $\mathrm{P}$ entry from the xylem (Eq. 10) and $s_{1}$ and $s_{2}$ are fitting parameters. Initial values for the leaf $\left(M_{L}\right), \mathrm{C}\left(M_{C}\right)$ and $\mathrm{P}\left(M_{P}\right)$ mass are $1 \times 10^{-4}$, 0 and $1 \times 10^{-7} \mathrm{~kg}$ respectively.

\section{Whole crop model}

In order to provide feedback between the root model and leaf model, we allow $\mathrm{C}$ mass to affect the root growth rate. Increasing $\mathrm{C}$ mass will increase root growth which in turn will increase plant $\mathrm{P}$ uptake. Through the process of photosynthesis, increasing plant $\mathrm{P}$ uptake will also increase $\mathrm{C}$ mass, thus creating a positive feedback loop.

The order $i$ root growth rate is now dependent on $\mathrm{C}$ as well as temperature, therefore we replace Eq. 1 with,

$\frac{\partial l_{i}}{\partial t}=r(T, C)\left(1-\frac{l_{i}}{L_{i}}\right)$,

where the rate of growth $r(T, C)$ is given by a function of temperature multiplied by a function of $\mathrm{C}$ $(r(T, C)=f(C) g(T))$,

$f(C)=\frac{\alpha_{c} M_{C}}{\gamma_{C}+M_{C}}$

$g(T)=\left\{\begin{array}{cc}0 & T \leq 5^{\circ} C \\ A(T-5) & T>5^{\circ} C\end{array}\right.$, where $\gamma_{C}$ is the mass of $\mathrm{C}$ when the root system is at half its maximum size, $\alpha_{C}$ is the strength of the $\mathrm{C}$ effect and $A$ is a fitting parameter determining the strength of temperature dependence on root growth rate. Below critical temperature $\left(5^{\circ} \mathrm{C}\right)$ there is no root growth and this reflects cold periods over the winter (SylvesterBradley et al. 2008).

Calibration

The parameter list for the models above is given in Table 1. A subset of these parameters are fitted to the experimental data and their values can be seen in Table 2. To begin the calibration process, the leaf model is first fit against the experimental above ground dry mass data, by changing 4-6 parameters $\left(\beta_{c}, k_{1}, f_{c}, f_{p}\right.$ for spring barley and in addition $s_{1}$ and $s_{2}$ for winter barley). In the leaf model only, we set the rate of $\mathrm{P}$ entry from the xylem $(F(c, z, t)$, Eq. 10) proportional to the experimental plant $\mathrm{P}$ uptake to simulate a representative plant $\mathrm{P}$ root uptake. We then combine the models, i.e. let the rate of $\mathrm{P}$ entry from the xylem be estimated from the root model, and fit for the remaining parameters $\left(\gamma_{c}\right.$ and $\left.\alpha_{c}\right)$.

During the calibration step we minimise the sum of squares value between the model's output for plant $\mathrm{P}$ uptake and above ground dry mass values against the experimental data values for the control and maximum applied P scenario ( 0 and $90 / 120 \mathrm{~kg} \mathrm{P} \mathrm{ha}^{-1}$ respectively). With the fitted parameters we then run the model for all applied $\mathrm{P}$ scenarios.

The differences between modelling spring barley and winter barley are the time they are grown for (151 and 313 days, respectively), the initial $\mathrm{P}$ profile in the soil $\left(20 \mathrm{mg} \mathrm{P}^{-1}\right.$ decay profile and $16 \mathrm{mg} \mathrm{P}$ $1^{-1}$ constant profile, respectively) and leaf growth dependence (also depending upon air temperature for winter barley).

\section{Results}

We compare two sets of barley field experimental data against the coupled model, the leaf model (where plant $\mathrm{P}$ uptake is given by experimental data) and the root model. The aim is to address the differences between the models and how well they fit the experimental field data for barley. 
Fig. 1 A flow diagram for the leaf model which estimates phosphate, carbon and above ground dry mass as mathematically described by Eqs. 18-22

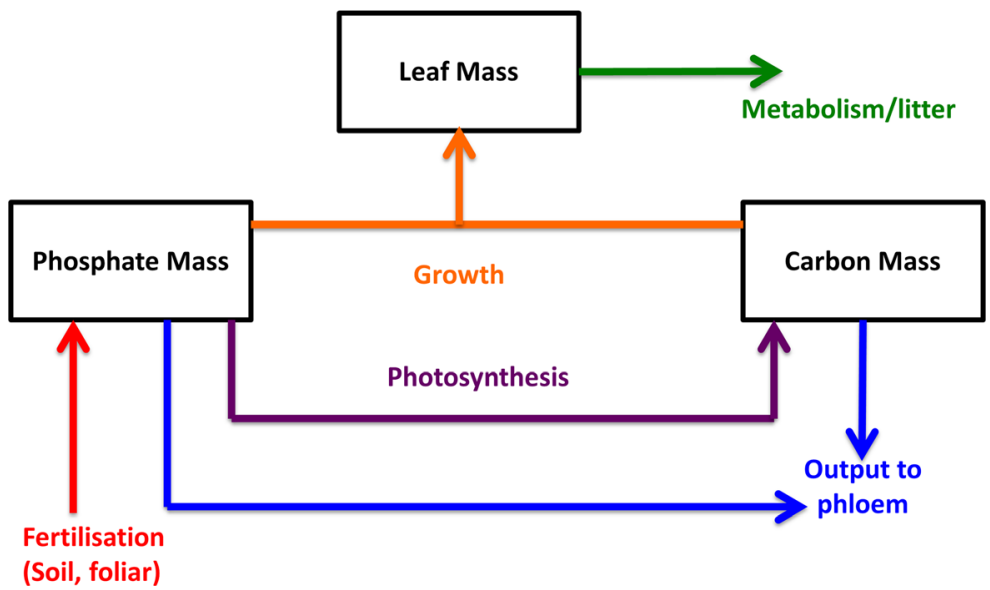

First we compare the values for plant $\mathrm{P}$ uptake between the root and coupled model for spring barley at three different growth stages, GS31, GS45 and GS91 for seven applied $\mathrm{P}$ rates $(0,5,10,20,30,60$ and $90 \mathrm{~kg} P$ ha $^{-1}$; Fig. 2). The coupled model estimates higher plant P uptake compared to the root model, better fitting the experimental data; staying within one standard deviation except at high applied $\mathrm{P}$ rates $(30,60$ and $90 \mathrm{~kg} \mathrm{P}$ $\mathrm{ha}^{-1}$ at GS31, 20, 60 and $90 \mathrm{~kg} \mathrm{P} \mathrm{ha}^{-1}$ at GS45 and 30 and $60 \mathrm{~kg} \mathrm{P} \mathrm{ha}{ }^{-1}$ at GS91). The feedback effect within the coupled model enables the root structure to become larger than in the root model and therefore the roots explore more of the soil and hence achieve an increased plant $\mathrm{P}$ uptake. The final model estimate (GS91) is more accurate than the earliest (GS31) due to not capturing the effects of possible lateral root proliferation due to higher applied P rates (Drew 1975). Early differences are averaged out as the root system grows.

When considering plant $\mathrm{P}$ uptake in winter barley, the coupled model behaves similarly to the root model (Fig. 3). At GS92, both models under-predict plant P uptake for the same reasons as stated in Heppell et al. (2015); the $P$ profile is depleted which limits the amount of $\mathrm{P}$ available for uptake, and perhaps the total amount of $\mathrm{P}$ in the soil was different to that estimated by the one soil test for the whole site (Olsen P index 1). The effect of slow release $\mathrm{P}$ pools in the soil was not taken into consideration due to the fact experimental data for this phenomenon was not available.

By coupling the root model with the leaf model we are able to compare measured above ground dry mass values against the coupled and leaf model only for both spring barley (Fig. 4) and winter barley (Fig. 5) for different applied $\mathrm{P}$ rates. The coupled model accurately predicts above ground dry mass at GS91 for spring barley, however it estimates a more average value for earlier growth stages; not distinguishing any differences between applied $\mathrm{P}$ rates. The large errors bars in the experimental above ground dry mass data are possibly due to field variation, making it hard to distinguish any differences between applied $\mathrm{P}$ rates, especially at later growth stages (the experimental differences are not statically significant). In addition, the variation in experimental plant P uptake values for GS31 is less than for GS91 (18 to $24 \%$ ), implying little correlation between early and late plant $\mathrm{P}$ uptake (adjusted $\mathrm{r}^{2}=0.4$ ). For winter barley, the coupled model is able to match above ground dry mass at GS39, but vastly underestimates it at GS92 due to underestimating plant $\mathrm{P}$ uptake as mentioned above. The leaf model fits well across all scenarios for spring and winter barley as it takes the known plant $\mathrm{P}$ uptake from the experimental data as an input.

The leaf model component allows us to estimate $\mathrm{P}$ (Fig. 6) and C mass (Fig. 7) in the above ground tissue over the growing period of the crop. The estimated $\mathrm{P}$ mass is higher in the leaf model compared to the coupled model for both spring and winter barley. The estimated $\mathrm{C}$ mass is higher in the leaf model compared to the coupled model for winter barley, but the other way around for spring barley. In the winter barley case, the increased $\mathrm{C}$ and $\mathrm{P}$ masses in the leaf model are due to higher plant $\mathrm{P}$ uptake values (Fig. 3 compared to Fig. 2) resulting in a larger end above ground dry mass. For spring barley, $\mathrm{C}$ mass in the coupled model begins lower and ends higher compared to the leaf model because plant $P$ uptake by the root system also begins lower and ends higher ( $\mathrm{P}$ uptake remains constant in the leaf model). The sudden decrease in $\mathrm{C}$ and $\mathrm{P}$ mass, for winter 
Table 1 A list of the parameters used for the 3 models: leaf, root and coupled

\begin{tabular}{|c|c|c|c|}
\hline Parameter & Definition & Value & Units \\
\hline \multicolumn{4}{|c|}{ Leaf model (Values from Thornley, J. H., 1995) } \\
\hline$k_{G}$ & Leaf growth rate constant & 1000 & $\left(\frac{\mathrm{kg} \mathrm{C}}{\text { kg Leaf }} \frac{\mathrm{kg} \mathrm{P}}{\mathrm{kg} \mathrm{Leaf}} \text { day }\right)^{-1}$ \\
\hline$k_{\text {litt }}$ & Leaf litter rate constant & 0.05 & day $^{-1}$ \\
\hline$k_{\text {mlitt }}$ & Leaf litter Michealis-Menten constant & 0.5 & $\mathrm{~kg}$ Leaf \\
\hline$k_{C}$ & Photosynthesis constant & 0.1 & $\frac{\mathrm{kg} \mathrm{C}_{\mathrm{kg} \mathrm{Leaf}}}{\mathrm{day}^{-1}}$ \\
\hline$k_{M}$ & Leaf self-shading constant & 1 & $\mathrm{~kg}$ Leaf \\
\hline$J_{C}$ & Carbon product inhibition constant & 0.1 & $\frac{\mathrm{kg} \mathrm{C}}{\mathrm{kg} \mathrm{Leaf}}$ \\
\hline$f_{c}$ & Fraction of $\mathrm{C}$ used for leaf growth & (fitted) & $\frac{\mathrm{kg} \mathrm{C}}{\mathrm{kg} \mathrm{Leaf}}$ \\
\hline$f_{p}$ & Fraction of $\mathrm{P}$ used for leaf growth & (fitted) & $\frac{\mathrm{kg} \mathrm{P}}{\mathrm{kg} \text { Leaf }}$ \\
\hline$k_{1}$ & P used for photosynthesis & (fitted) & $\frac{\mathrm{kg} \text { Leaf }}{\mathrm{kg} \mathrm{P}}$ \\
\hline$k_{p}$ & $\mathrm{P}: \mathrm{C}$ ratio for photosynthesis production & $0.005-0.05$ & $\frac{\mathrm{kg} \mathrm{P}}{\mathrm{kgCC}}$ \\
\hline$\beta_{p}$ & Rate of P output to phloem & 0 & $\frac{\mathrm{kg} \text { Leaf }}{\text { day }}$ \\
\hline$F$ & Rate of P entry from xylem & $\begin{array}{l}\text { Taken from barley } \\
\text { experimental data or } \\
\text { root model output }\end{array}$ & $\frac{\mathrm{kgP}}{\text { day }}$ \\
\hline$A_{T}$ & Air temperature & $\begin{array}{l}\text { Taken from Local Met } \\
\text { office MIDAS stations }\end{array}$ & ${ }^{\circ} \mathrm{C}$ \\
\hline$\beta_{c}$ & Rate of C output to phloem & (fitted) & $\frac{\mathrm{kgL}}{\text { day }}$ \\
\hline$s_{1}$ & Air temperature slope constant & (fitted) & - \\
\hline$s_{2}$ & Air temperature transition constant & (fitted) & ${ }^{\circ} \mathrm{C}$ \\
\hline \multicolumn{4}{|c|}{ Root-soil model (values from Heppell et al. 2015) } \\
\hline$D_{0}$ & Water diffusivity & $10^{3}$ & $\mathrm{~cm}^{2}$ day $^{-1}$ \\
\hline$K_{s}$ & Water hydraulic conductivity & 5 & $\mathrm{~cm} \mathrm{day}^{-1}$ \\
\hline$D_{f}$ & $\mathrm{P}$ diffusivity in free water & $10^{-5}$ & $\mathrm{~cm}^{2}$ day $^{-1}$ \\
\hline$d$ & Impedance factor & 2 & - \\
\hline$a$ & Main order root radius & 0.085 & $\mathrm{~cm}$ \\
\hline$a_{1}$ & first order root radius & 0.060 & $\mathrm{~cm}$ \\
\hline$k_{r}$ & Root radial water conductivity & $7.85^{*} 10^{-6}$ & $\mathrm{~m}^{2} \mathrm{~s}^{-1} \mathrm{MPa}^{-1}$ \\
\hline$k_{z}$ & Root axial hydraulic conductivity & $1.198 * 10^{-2}$ & $\mathrm{~m}^{4} \mathrm{~Pa}^{-1} \mathrm{~s}^{-1}$ \\
\hline$\psi_{1}$ & Density of first order roots & 2.33 & $\mathrm{~cm}^{-1}$ \\
\hline$p_{r}$ & Root internal xylem pressure & 1 & $\mathrm{~Pa}$ \\
\hline$p_{c}$ & Characteristic suction pressure & 0.0232 & $\mathrm{MPa}$ \\
\hline$L_{0}$ & Max length of main order root & 150 & $\mathrm{~cm}$ \\
\hline$L_{1}$ & Max length of first order root & 7.9 & $\mathrm{~cm}$ \\
\hline$L$ & Root tip position & $0-L_{0}$ & $\mathrm{~cm}$ \\
\hline$b$ & Buffer power & 23.28 & - \\
\hline$\theta$ & $\begin{array}{l}\text { Angle between the main root and first } \\
\text { order branches }\end{array}$ & 60 & degrees \\
\hline$\phi$ & Porosity of soil & 0.3 & - \\
\hline$p_{r}^{0}$ & Initial root internal xylem pressure & 1 & $\mathrm{~Pa}$ \\
\hline$\lambda_{1}$ & Root internal xylem pressure parameter & $2.7 * 10^{-3}$ & $\mathrm{~Pa} / \operatorname{deg} \mathrm{C}$ \\
\hline$\lambda_{2}$ & Root internal xylem pressure parameter & $8.46^{*} 10^{-4}$ & $\mathrm{~Pa} / \%$ humidity \\
\hline$\lambda_{3}$ & Root internal xylem pressure parameter & $7.9 * 10^{-2}$ & $\mathrm{~Pa}$ \\
\hline
\end{tabular}


Table 1 (continued)

\begin{tabular}{|c|c|c|c|}
\hline Parameter & Definition & Value & Units \\
\hline$\delta$ & Flux of water parameter & $2.69 * 10^{-2}$ & - \\
\hline$\alpha$ & Flux of water parameter & $1.2 * 10^{-6}$ & $\mathrm{~m} \mathrm{~s}^{-1}$ of water \\
\hline$\beta$ & Flux of water parameter & $2.22 * 10^{-6}$ & $\mathrm{~m} \mathrm{~s}^{-1}$ of water/degC \\
\hline$\gamma$ & Flux of water parameter & $5.35 * 10^{-4}$ & $\mathrm{~m} \mathrm{~s}^{-1}$ of water/ $\mathrm{m} \mathrm{s}^{-1}$ of air \\
\hline$E$ & Flux of water parameter & $5^{*} 10^{-4}$ & $\mathrm{~m} \mathrm{~s}^{-1}$ of water \\
\hline$l_{w}$ & Bottom of the soil & 200 & $\mathrm{~cm}$ \\
\hline \multicolumn{4}{|c|}{ Coupled model } \\
\hline$\gamma_{C}$ & Root carbon growth parameter & (fitted) & - \\
\hline$\alpha_{c}$ & Strength of carbon effect on root growth & (fitted) & - \\
\hline$A$ & Strength of temperature dependence on root growth rate & 0.0780 & - \\
\hline
\end{tabular}

barley, around the 250 day mark is due to the enforced halting of the root growth rate.

The root growth rate is affected by $\mathrm{C}$ mass (spring barley) and also temperature (winter barley); therefore different final root lengths can be observed between model simulations (Fig. 8). The leaf model created a longer root length compared to the coupled model in the winter barley scenario due to the early differences in $\mathrm{C}$ mass. For spring barley, the early $\mathrm{C}$ mass values for the coupled and leaf model were similar resulting in almost identical root growth rates and hence final root lengths. As $\mathrm{C}$ mass increases above a certain value any differences are masked when affecting the root growth rate. There was little difference in root length between the two different fertiliser applications $\left(0\right.$ and $\left.90 / 120 \mathrm{~kg} \mathrm{P} \mathrm{ha}^{-1}\right)$, the largest being between the coupled model for winter barley GS92. Due to the small increase in plant $\mathrm{P}$ uptake between scenarios ( 0 and $120 \mathrm{~kg} \mathrm{P} \mathrm{ha}^{-1}$ ) there was little effect on increasing root length via the slow feedback loop created by the addition of the leaf model. Chemotropism effects from adding large amounts of $\mathrm{P}$ fertiliser could perhaps explain any differences between plant $\mathrm{P}$ uptake values at early growth stages. In the winter barley scenario, as root growth rate was dependent upon temperature, we see periods of no root growth matching periods of low temperature, as expected.

Heppell et al. (2015) considered the effects of discrete placing of fertiliser within the root zone against incorporating fertiliser throughout the soil for a range of cultivation options (mix 25, 20 and $10 \mathrm{~cm}$, inverted plough, minimum tillage and no cultivation) for winter barley at
GS92. We do the same in this paper for the new coupled model (Fig. 9). We arrive at the same overall conclusion, placing fertiliser rather than incorporating achieves a higher plant $\mathrm{P}$ uptake estimate and under a wet climate (x5 flux of water at soil surface), such as in the UK, this difference decreases (9.9\% to $0.3 \%$ and $9.8 \%$ to $4.5 \%$ ) over no cultivation for a dry and wet climate respectively. Ploughing was also the best cultivation option moving top soil $\mathrm{P}$ to a lower depth, making it more accessible to a comparatively larger root system.

\section{Discussion}

In order to obtain a more accurate representation of the growth of barley throughout a crop life cycle we have combined a below ground root-soil model with an above ground leaf model. By combining the two models we

Table 2 The fitted parameter set for the leaf and coupled models, for spring barley and winter barley

\begin{tabular}{llll}
\hline Parameter & & $\begin{array}{l}\text { Value for } \\
\text { spring barley }\end{array}$ & $\begin{array}{l}\text { Value for } \\
\text { winter barley }\end{array}$ \\
\hline Leaf model & $\beta_{c}$ & 0.0001 & 0.0001 \\
& $\mathrm{k}_{1}$ & 100 & 859 \\
& $\mathrm{f}_{\mathrm{c}}$ & 0.5 & 0.5 \\
& $\mathrm{f}_{\mathrm{p}}$ & $7 * 10^{-4}$ & $1.6^{*} 10^{-3}$ \\
& $s_{1}$ & $\mathrm{n} / \mathrm{a}$ & 20.78 \\
& $s_{2}$ & $\mathrm{n} / \mathrm{a}$ & -1.446 \\
Coupled model & $\gamma_{C}$ & $1.30^{*} 10^{-5}$ & $1.31^{*} 10^{-4}$ \\
& $\alpha_{c}$ & 1 & 1.982 \\
\hline
\end{tabular}


Fig. 2 Spring barley plant $\mathrm{P}$ uptake experimental data values for different applied $\mathrm{P}$ rates $(0,5$, $10,20,30,60$ and $90 \mathrm{~kg} \mathrm{P}^{-1}$ ) with standard deviation, compared against estimates from the coupled model and root model at GS31, 45, 91

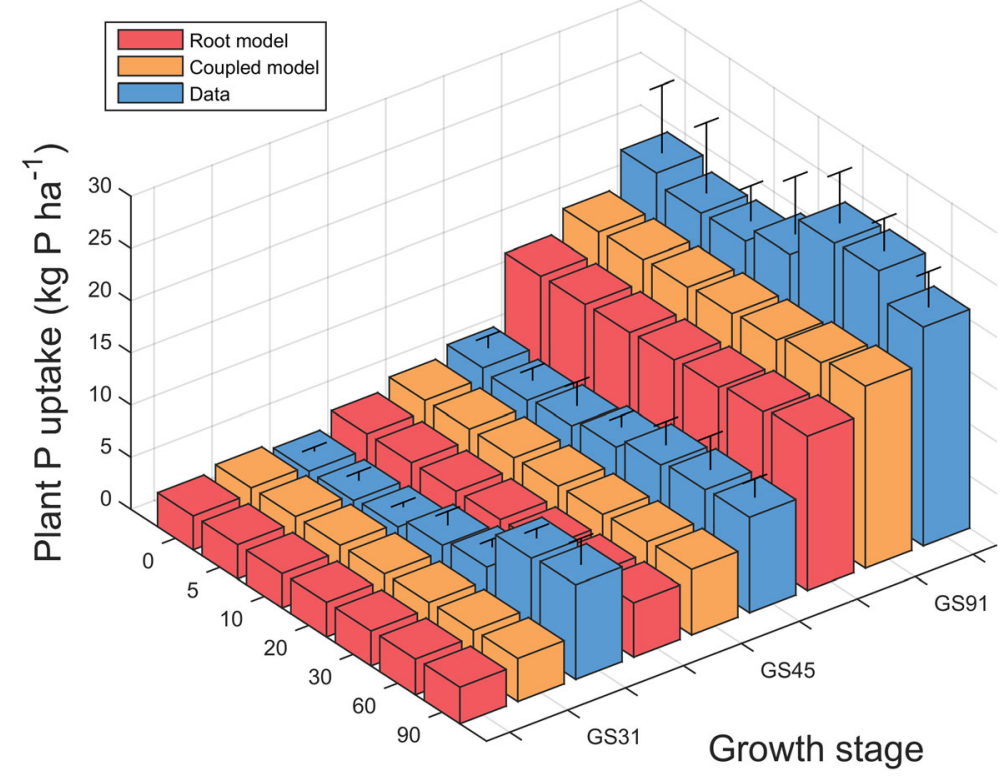

Applied P (kg P ha $\left.{ }^{-1}\right)$ are able to let an above ground process (photosynthesis) affect a below ground process (root growth) and vice versa. $\mathrm{C}$ is created via photosynthesis in the leaf model (dependent upon above ground dry mass and P) and stimulates root growth; increased root growth increases plant $\mathrm{P}$ uptake and hence above ground dry mass. This positive feedback effect could explain why crops with early plant $\mathrm{P}$ uptake levels grow more vigorously and can produce higher yields (Brenchley 1929; Boatwright and Viets 1966; Green et al. 1973; Grant et al. 2001). Due to possible unfavourable (e.g. dry) weather conditions, maximising early plant $\mathrm{P}$ uptake through greater
Fig. 3 Winter barley plant $P$ uptake experimental data values for different applied $\mathrm{P}$ rates $(0,15$, $30,60,90$ and $120 \mathrm{~kg} \mathrm{P} \mathrm{ha}^{-1}$ ) with standard deviation, compared against estimates from the couple model and root model at GS39 and 92

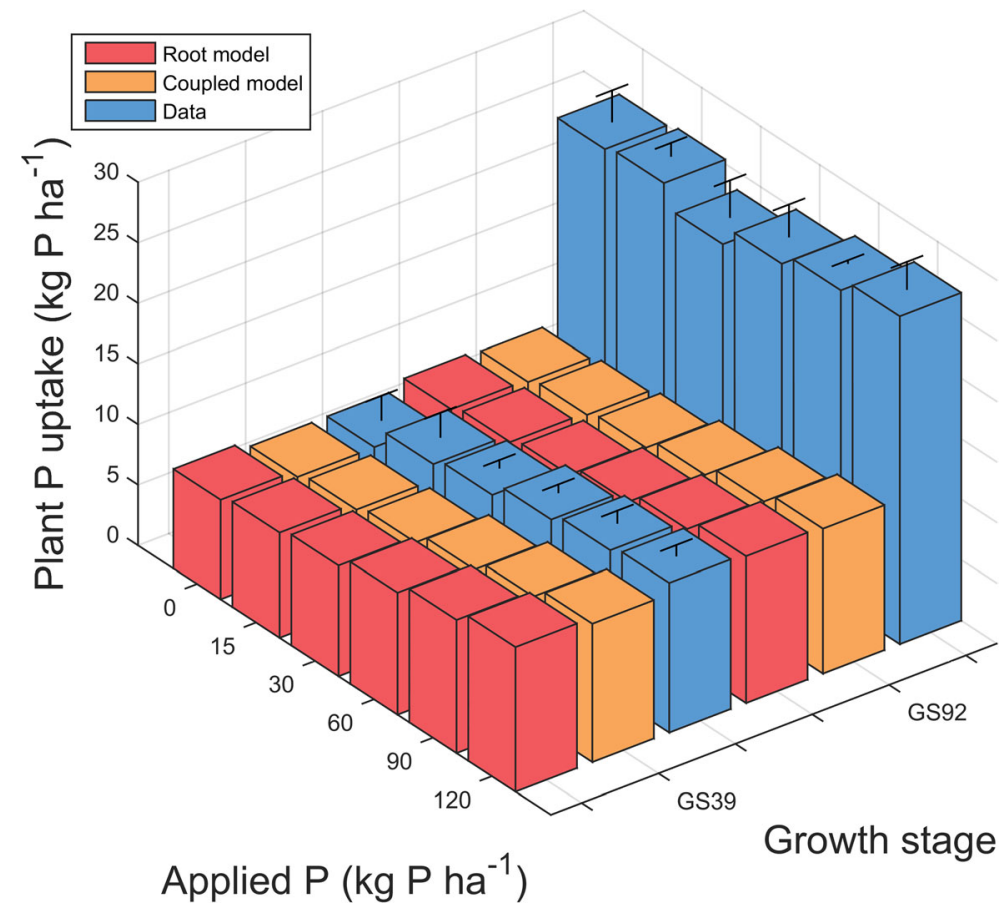


Fig. 4 Spring barley above ground dry mass experimental data values for different applied $\mathrm{P}$ rates $(0,5,10,20,30,60$ and $90 \mathrm{~kg} \mathrm{P} \mathrm{ha}{ }^{-1}$ ) with standard deviation, compared against estimates from the coupled model and leaf model at GS31, 45, 91

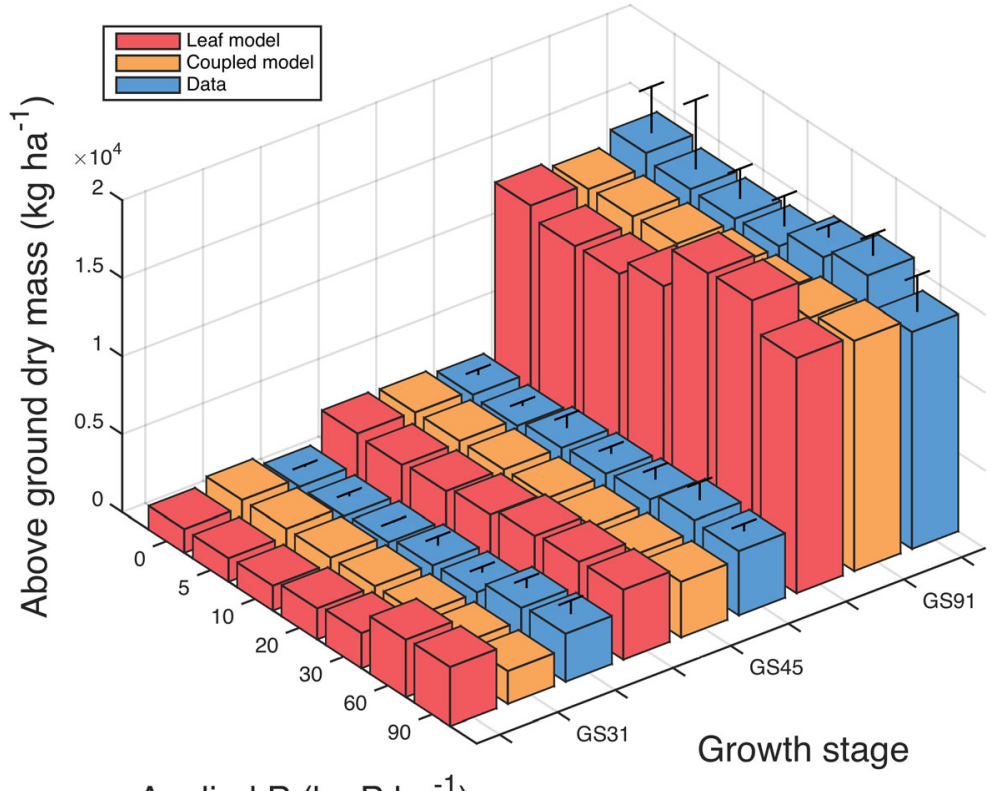

Applied P (kg P ha $\left.{ }^{-1}\right)$ root proliferation is also a good strategy to help ensure continuing capture of soil resources at later stages of growth.

From the modelling work conducted we can postulate that the whole crop model accurately estimates above ground dry mass at all growth stages given it has accurate estimates of plant $\mathrm{P}$ uptake (an average difference of $4.6 \%$ for the whole crop model for above ground dry mass, compared to $15.8 \%$ when using values one standard deviation away from the experimental data). Using the calibrated whole crop model we found the optimal fertiliser and cultivation scenario is to use a plough and place the $\mathrm{P}$ fertiliser. The largest increase in plant $\mathrm{P}$ uptake when placing fertiliser over
Fig. 5 Winter barley above ground dry mass experimental data values for different applied $\mathrm{P}$ rates $(0,15,30,60,90$ and $120 \mathrm{~kg}$ $\mathrm{P} \mathrm{ha}^{-1}$ ) with standard deviation, compared against estimates from the coupled model and leaf model at GS39 and 92

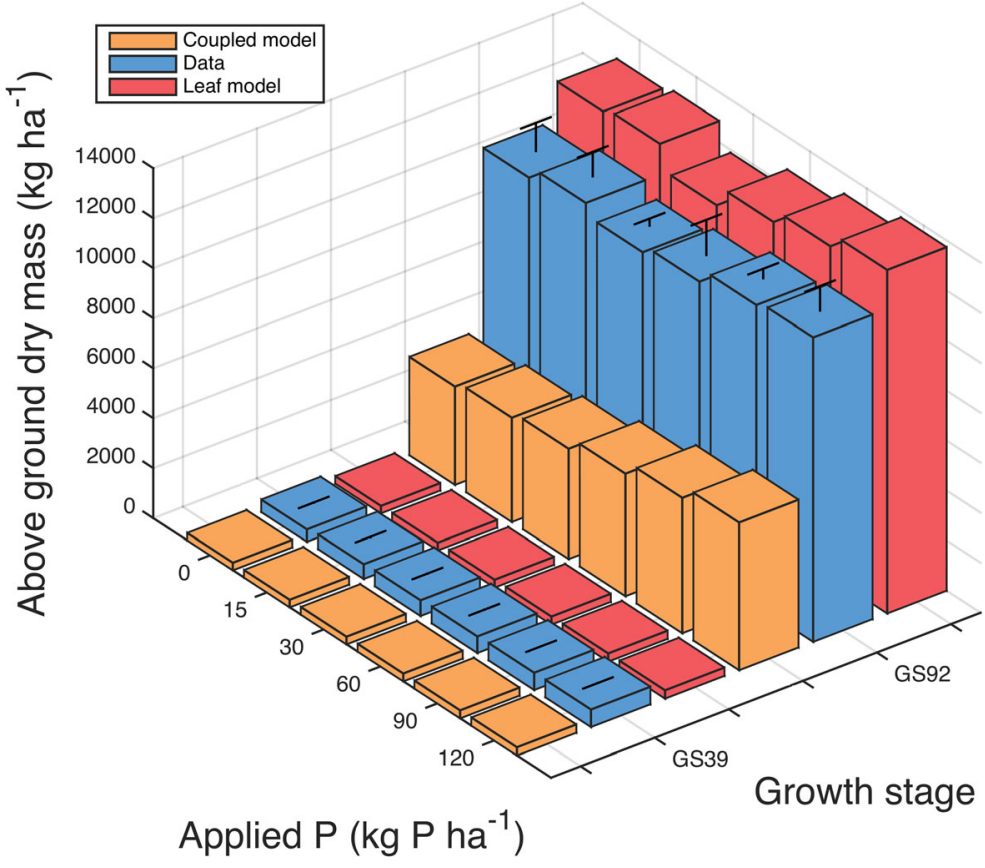


Fig. 6 Estimated above ground phosphate mass values from the coupled model and leaf model for a spring barley and $\mathbf{b}$ winter barley at GS91, 92 respectively for $0 \mathrm{~kg} \mathrm{P} \mathrm{ha}^{-1}$ and $90 / 120 \mathrm{~kg} \mathrm{P}$ $\mathrm{ha}^{-1}$
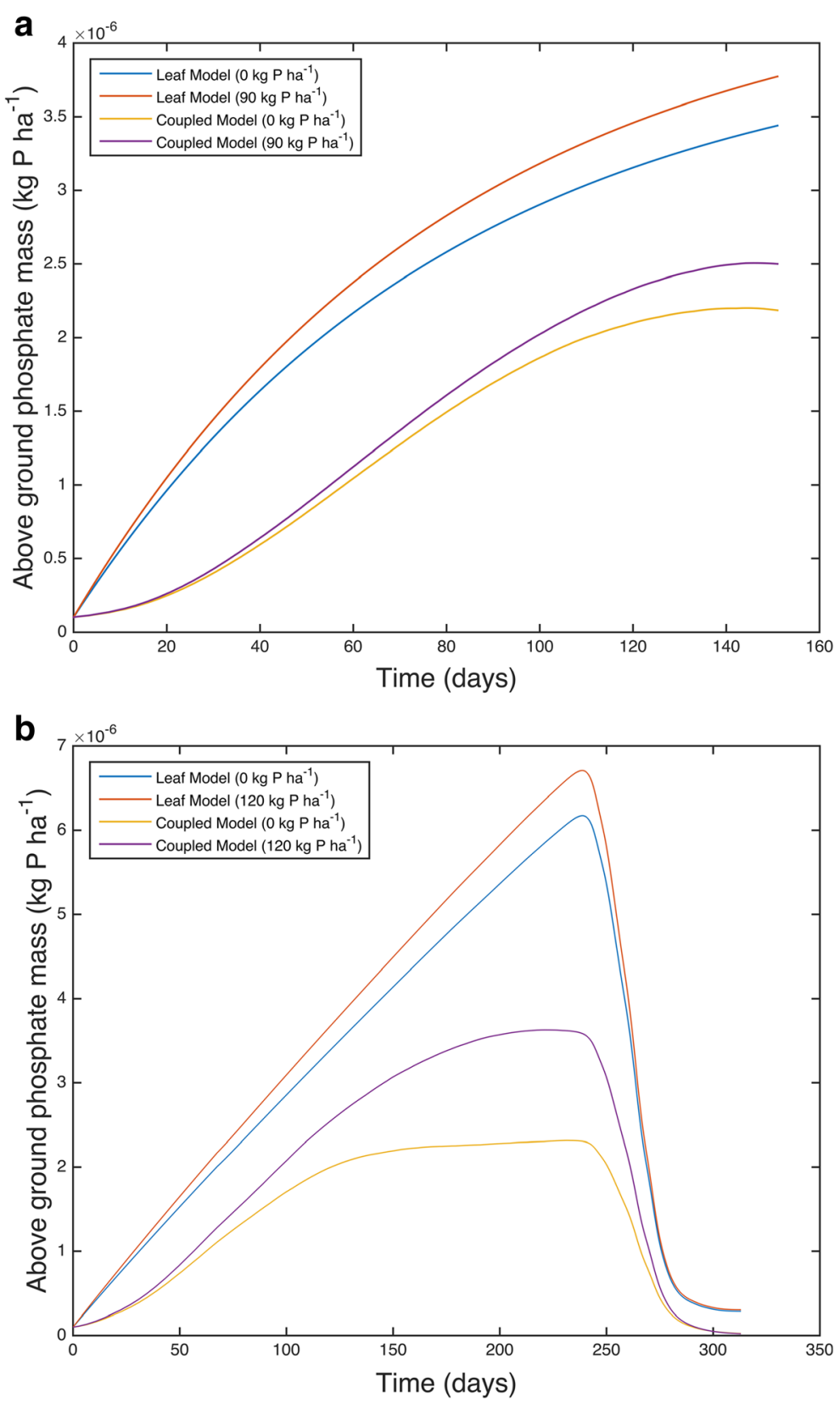

incorporating fertiliser was $9.6 \%$ (plough, dry climate). The difference between incorporating and placing has been long studied and depends upon a range of criteria such as soil $\mathrm{P}$ concentration, soil temperature, crop species and price (Devine et al. 1964; Mahler 2001). Owusu-Gyimah et al. (2013) found that applying fertiliser at a depth of 10 and $20 \mathrm{~cm}$ away from the plant (placed P) gave the best outcome for maize growing under tropical conditions. By placing fertiliser instead of incorporating it throughout the soil the available $\mathrm{P}$ is being put where the root system is going to grow hoping to ensure early plant $\mathrm{P}$ uptake and a more successful crop. Hence Wager et al. (1986) found that P fertilizer application rates could be halved by placing fertiliser instead of incorporation because the applied $\mathrm{P}$ was more efficiently used. However, optimal fertiliser and cultivation methods depend on the initial soil P condition/ distribution (Randall and Hoeft 1988); this includes at the depth at which existing $P$ is initially available within the soil (Heppell et al. 2015). 
Fig. 7 Estimated above ground carbon mass values from the coupled model and leaf model for a spring barley and $\mathbf{b}$ winter barley at GS91, 92 respectively for $0 \mathrm{~kg} \mathrm{P} \mathrm{ha}^{-1}$ and $90 / 120 \mathrm{~kg} \mathrm{P}$ $\mathrm{ha}^{-1}$
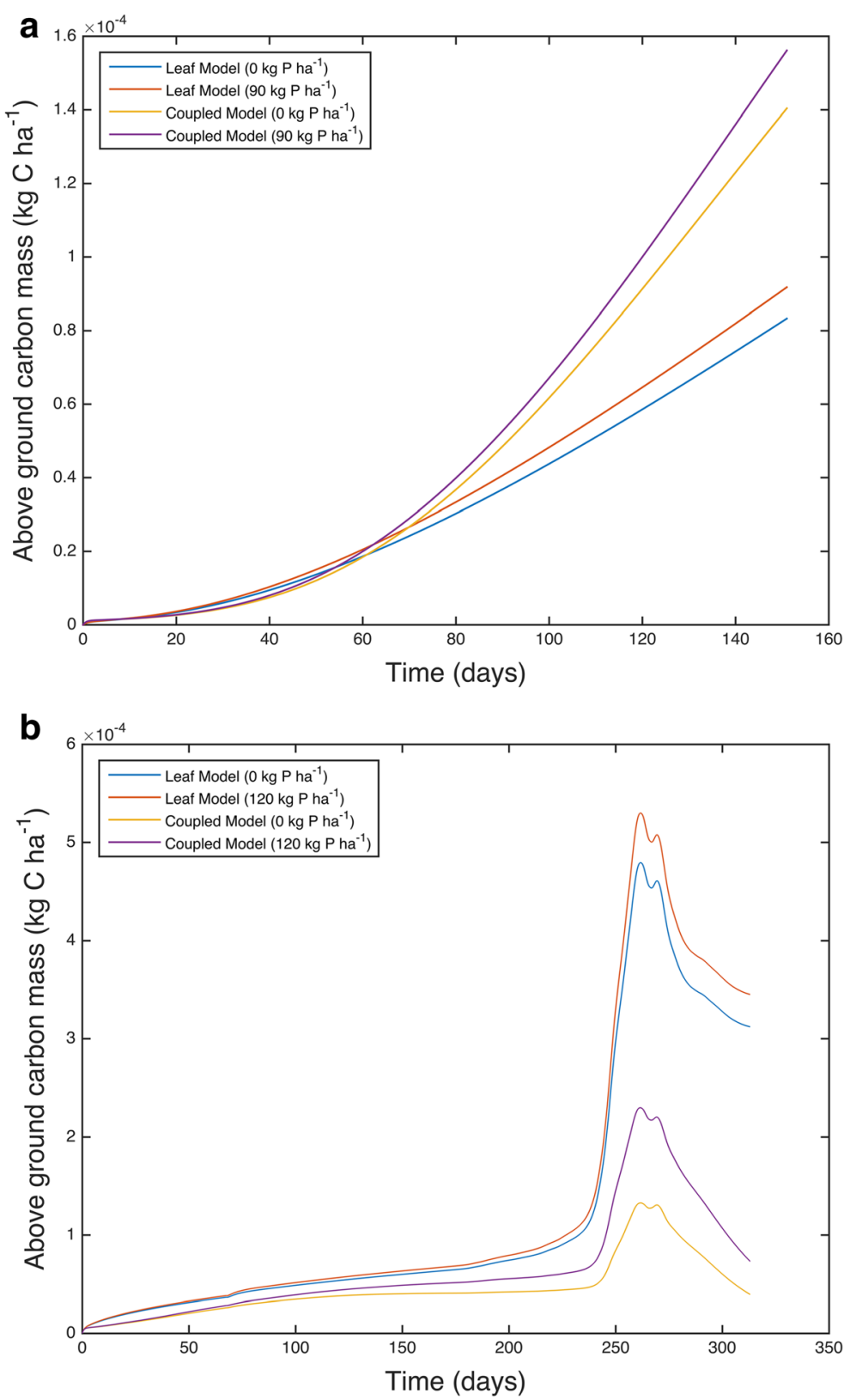

For modelling across countries it will be important to measure soil available $\mathrm{P}$ levels consistently, by either using a common method or a set of common descriptors. Although, an international 'standard' soil extraction method is not necessarily needed; rather employing a basic soil property (e.g. sorption/buffer capacity) would be better to calibrate fertiliser recommendations. Modelling is the most appropriate way to overcome the problems of site specificity in soil $\mathrm{P}$ supply that confound current soil $\mathrm{P}$ test methods which do not apply to all soil types, i.e. across countries. Countries generally adopt a particular standard method for soil P tests; many different extractants are used. However, these do not necessarily give correlated results, for example across European laboratories (Neyroud and Lischer 2002; Jordan-Meille et al. 2012). It is possible that a more robust soil test will be developed in the future, that more accurately reflects immediate $\mathrm{P}$ availability to roots across different soil types. For example, using 
Fig. 8 Estimated plant root length values from the root model, coupled model and leaf model for a spring barley and $\mathbf{b}$ winter barley at GS91, 92 respectively for $0 \mathrm{~kg} \mathrm{P} \mathrm{ha}^{-1}$ and 90/120 kg P ha ${ }^{-1}$
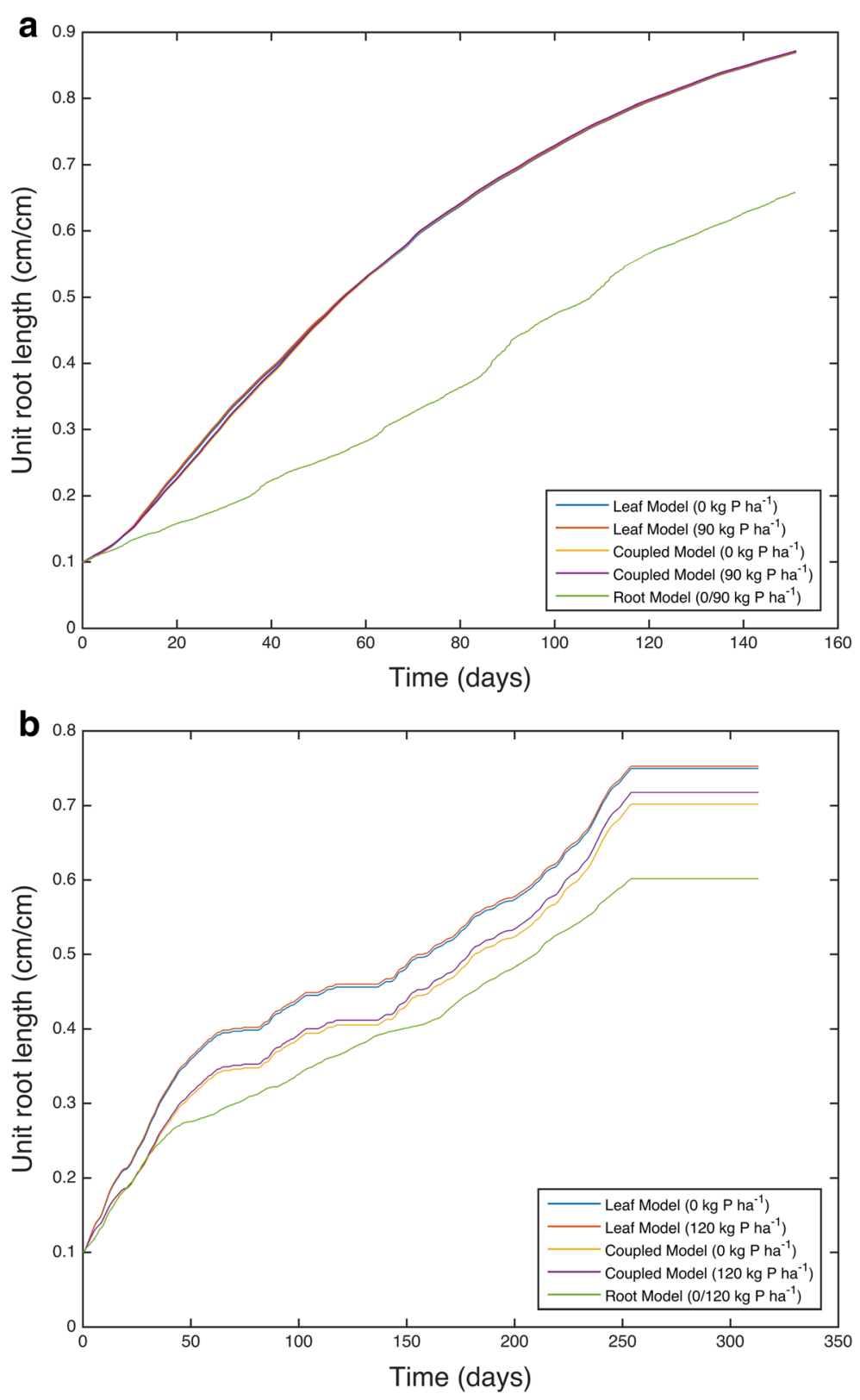

Diffusive Gradient in Thin films (DGT) based on soil P diffusion rates (Van Rotterdam et al. 2009; Tandy et al. 2011) or a method that mimics root $P$ acquisition traits (De Luca et al. 2015). The use of more mechanistic approaches to calculate soil available $P$ levels via a more standardised test, or a combination of tests, enhances their applicability across a wider variety of soil types and may lead to more accurate assessment of fertiliser needs (Van Rotterdam et al. 2014). Also, given that patterns of $P$ concentration with depth in soil profiles vary between sites (Jobbágy and Jackson 2001), it may also be important to assess surface stratification in no-tilled soils or in subsoils. Over-fertilising soils due to inaccurate estimation of requirement, or mis-interpretation of soil $\mathrm{P}$ supply through inappropriate tests leads not only to waste of finite reserves of phosphate-rock but also increased risk of $P$ loss to water causing eutrophication (Hooda et al. 2001). By using knowledge about the distribution of $\mathrm{P}$ within the soil and by 
Fig. 9 Estimated plant $\mathrm{P}$ uptake values for winter barley at GS92 for a set of fertiliser and soil management strategies (mix 25, 20 and $10 \mathrm{~cm}$, inverted plough, minimum tillage and no cultivation, and either no fertiliser, $90 \mathrm{~kg} \mathrm{P} \mathrm{ha}^{-1}$ incorporated or $90 \mathrm{~kg} \mathrm{P} \mathrm{ha}^{-1}$ placed) for a normal climate and a wetter climate ( $\mathrm{x} 5$ flux of water at soil surface)

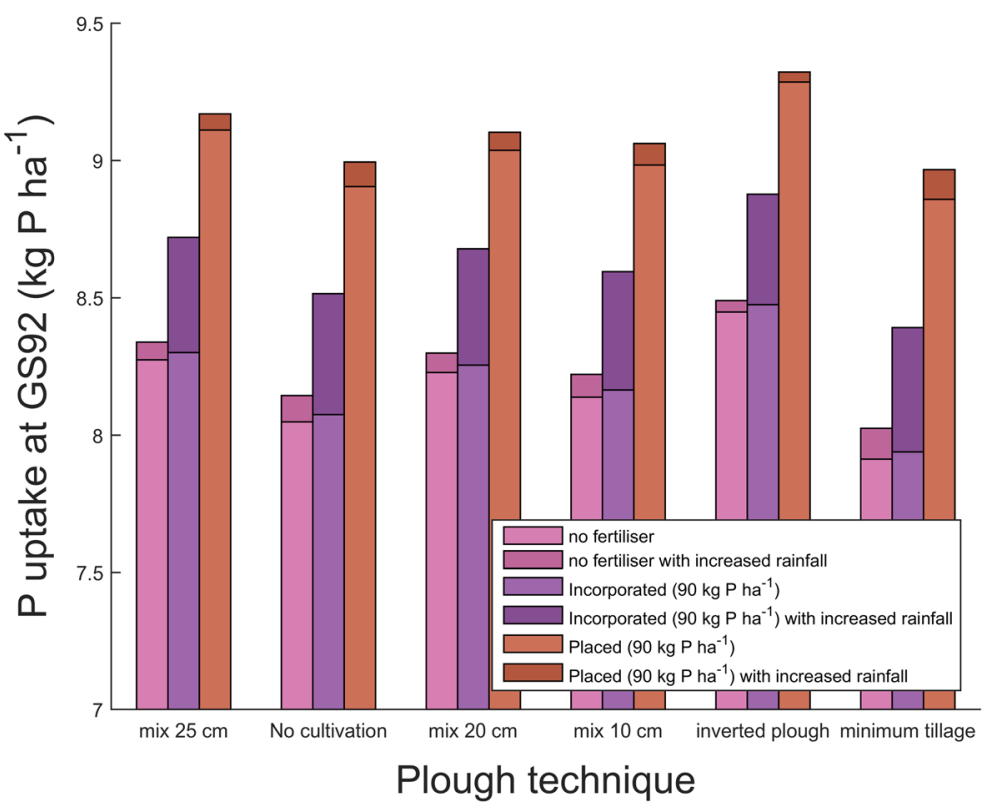

modelling its implications, it should be possible to save on fertiliser costs by implementing better optimised treatments through targeting P use (Yang et al. 2013; Withers et al. 2014). Furthermore, since crop and fertiliser management have long-term effects on topsoil and subsoil $\mathrm{P}$ availability (Bolland and Baker 1998), it will be important to validate the model over several years if it is to improve on current simpler approaches to decision making. Additional model features would be needed, such as effects between cropping seasons, but would make for a more overall accomplished model. We note that the model would have to be calibrated separately for different crops.

Although there was little response to $\mathrm{P}$ application observed in the field trial in terms of plant $P$ uptake at late growth stages (GS91 for spring barley and GS92 for winter barley), there was a response at early growth stages (GS31 for spring barley and GS39 for winter barley). This early response could imply that there were limiting environmental factors beyond nutritional inputs. Cold and dry conditions in spring are known to inhibit the transport of P from the soil to the root (Grant et al. 2001). However, if the measured 'low' $P$ soil was an underestimation for the total amount of available $\mathrm{P}$ in the soil then this could explain the lack of response at harvest observed in the field. In addition, field variation could in part explain the early response to applied P; however as the root system became larger during the latter growth stages any difference in plant $\mathrm{P}$ uptake and resulting yield was evened out. Due to the complex nature of cereal physiology (Sylvester-Bradley et al. 2008), an early plant $P$ uptake response does not necessarily indicate a higher final plant $\mathrm{P}$ uptake and yield; because the plant compensates by taking up more $\mathrm{P}$ later on as temperatures warm up. The slow feedback effect is a good explanation of the long term behaviour of the crop, and estimation of total plant $\mathrm{P}$ uptake.

Potentially, new ways to improve efficiency use of P can now be developed by combining recent advances in application technology, sensing technology, geo-spatial information and modelling so as to apply $\mathrm{P}$ where it is needed and importantly not apply it where it is not needed. Precision farming equipment is being widely adopted; now, its effective deployment depends on whether the vast amount of data available about a given plot of land can be interpreted to improve the precision and decrease the risks compared to current decision making (Sylvester-Bradley et al. 1999). For example, soil nutrient maps, past yield maps, soil and canopy sensors and climate predictions may provide input data for integrated crop models to output quantitative predictions of fertiliser requirements so that application as sowing can be adjusted in real time. However, the more immediate and preliminary prospect is of using simulation models to compare scenarios of possible treatments, to help guide future 
soil and fertiliser management strategies, and to accompany continuing field testing.

Acknowledgments We would like to thank the BBSRC and DEFRA (BB/I024283/1) for funding S.P. and The Royal Society University Research Fellowship for funding T.R. K.C.Z. was partially funded by Award No. KUK-C1-13- 04 of the King Abdullah University of Science and Technology (KAUST); J.H. by EPSRC Postdoctoral Prize Fellowship; and S.P., P.T., D.L., R.S-B., A.C.E, R.W., P.W, D.L.J. and T.R. by DEFRA, BBSRC, Scottish Government, AHDB, and other industry partners through Sustainable Arable LINK Project LK09136.

Open Access This article is distributed under the terms of the Creative Commons Attribution 4.0 International License (http:// creativecommons.org/licenses/by/4.0/), which permits unrestricted use, distribution, and reproduction in any medium, provided you give appropriate credit to the original author(s) and the source, provide a link to the Creative Commons license, and indicate if changes were made.

\section{References}

Barber S (1984) Soil nutrient bioavailability: a mechanistic approach. Wiley-Interscience

Blackmore S (2014) Address to the Oxford Farming Conference. 8 January 2014. See http://www.ofc.org.uk/videos/2014/ vision-farming-robots-2050. Last Accessed 07/09/2015.

Boatwright G, Viets F (1966) Phosphorus absorption during various growth stages of spring wheat and intermediate wheatgrass. Agron J 58:185-188

Bolland M, Baker M (1998) Phosphate applied to soil increases the effectiveness of subsequent applications of phosphate for growing wheat shoots. Aust J Exp Agric 38(8):865-869

Brenchley W (1929) The phosphate requirement of Barley at different periods of growth. Ann Bot 43:89-112

Brown L (2012) Outgrowing the earth: the food security challenge in an age of falling water tables and rising temperatures. Taylor \& Francis. ISBN 1-84407-185-5

Conway G, Barbier E (1990) After the green revolution: sustainable agriculture for development. Earthscan, London, 978-184971-930-8

Cordell D, Drangert J, White S (2009) The story of phosphorus: global food security and food for thought. Glob Environ Chang 19:292-305

De Luca T, Glanville H, Harris M, Emmett B, Pingree M, De Sosa L, Morena C, Jones D (2015) A novel rhizosphere trait-based approach to evaluating soil phosphorus availability across complex landscapes. Soil Biol Biochem 88:110-119

Defra (2010) Fertiliser manual (RB209), 8th edn. The Stationary Office, London

Déry P, Anderson B (2007) Peak phosphorus. In: Energy Bulletin, 08/13/2007. Post Carbon Institute. Available: energybulletin.net/node/33164

Devine JJ, Gilkes R, Holmes MRJ (1964) Field experiments on the phosphate requirements of Spring wheat and barley. Exp Husb 11:88-97
Drew MC (1975) Comparison of the effects of a localised supply of phosphate, nitrate, ammonium and potassium on the growth of the seminal root system, and the shoot in Barley. New Phytol 75:479-490

Dunbabin V, Postma J, Schnepf A, Pagès L, Javaux M, Wu L, Leitner D, Chen Y, Rengel Z, Diggle A (2013) Modelling root-soil interactions using three-dimensional models of root growth, architecture and function. Plant Soil 372:93-124

Foyer C, Spencer C (1986) The relationship between phosphate status and photosynthesis in leaves. Planta 167(3):369-375

George T, Brown L, Newton A, Hallett P, Sun B, Thomas W, White P (2011) Impact of soil tillage on the robustness of genetic component of variation in phosphorus (P) use efficiency in barley (Hordeum vulgare L.). Plant Soil 339:113123

Grant C, Flaten D, Tomasiewicz D, Sheppard S (2001) The importance of early season phosphorus nutrition. Can J Plant Sci 81:211-224

Green D, Ferguson W, Warder F (1973) Accumulation of toxic levels of phosphorus in the leaves of phosphorus-deficient barley. Can J Plant Sci 53:241-246

Greenwood D, Karpinets T, Stone D (2001) Dynamic model for the effects of soil $\mathrm{P}$ and fertilizer $\mathrm{P}$ on crop growth, $\mathrm{P}$ uptake and soil $\mathrm{P}$ in arable cropping: model description. Ann Bot 88 : 279-291

Heppell J, Payvandi S, Zygalakis K, Smethurst J, Fliege J, Roose $\mathrm{T}$ (2014) Validation of a spatial-temporal soil water movement and plant water uptake model. Geotechnique 64(7): 526-539

Heppell J, Payvandi S, Talboys P, Zygalakis K, Fliege J, Langton D, Sylvester-Bradley R, Walker R, Jones DL, Roose T (2015) Modelling the optimal phosphate fertiliser and soil management strategy for crops. Plant Soil. doi:10.1007/s11104-0152543-0

Hooda P, Truesdale V, Edwards A, Withers P, Aitken M, Miller A, Rendell A (2001) Manuring and fertilization effects on phosphorus accumulation in soils and potential environmental implications. Adv Environ Res 5(1):13-21

Jeuffroy M, Vocanson A, Roger-Estrade J, Meynard J (2012) The use of models at field and farm levels for the ex ante assessment of new pea genotypes. Eur J Agron 42:68-78

Jobbágy E, Jackson R (2001) The distribution of soil nutrients with depth: global patterns and the imprints of plants. Biogeochemistry 53(1):51-77

Jones J, Hoogenboom G, Porter C, Boote K, Batchelor W, Hunt L, Wilkens P, Singh U, Gijsman A, Ritchie J (2003) The DSSAT cropping system model. Eur J Agron 18:235-265

Jordan-Meille L, Rub k G, Ehlert P, Genot V, Hofman G, Goulding K, Recknagel J, Provolo G, Barraclough P (2012) An overview of fertilizer-P recommendations in Europe: soil testing, calibration and fertilizer recommendations. Soil Use Manag 28(4):419-435

Keating B, Carberry P, Hammer G, Probert M, Robertson M, Holzworth D, Huth N, Hargreaves J, Meinke H, Hochman Z, McLean G, Verburg K, Snow V, Dimes J, Silburn M, Wang E, Brown S, Bristow K, Asseng S, Chapman S, McCown R, Freebairn D, Smith C (2003) An overview of APSIM, a model designed for farming systems simulation. Eur J Agron 18(3-4):267-288 
Kuchenbuch RO, Buczko U (2011) Re-visiting potassium- and phosphate-fertilizer responses in field experiments and soiltest interpretations by means of data mining. J Plant Nutr Soil Sci 174:171-185

Lindenmayer A (1968) Mathematical models for cellular interactions in development II. Simple and branching filaments with two-sided inputs. J Theor Biol 18(3):300-315

Lohry R (1998) Surface banding superior to broadcasting on reduced-till. Fluid J 22:14-18

Lynch J (2007) Roots of the second green revolution. Aust J Bot 55:493-512

Mahler R (2001) Fertilizer placement. CIS. Soil Scientist, Department of plant, Soil, and Entomological Sciences, University of Idaho

Neyroud J, Lischer P (2002) Do different methods used to estimate soil phosphorus availability across Europe give comparable results? J Plant Nutr Soil Sci 166(4):422-431

Nye P, Tinker P (1977) Solute movement in the soil-root system. Blackwell Science Publishers

Owusu-Gyimah V, Nyatuame M, Ampiaw F, Ampadu P (2013) Effect of depth and placement distance of fertilizer NPK 1515-15 on the performance and yield of maize plant. Int $J$ Agron Plant Prod 4(12):3197-3204

Randall G, Hoeft R (1988) Placement methods for improved efficiency of $\mathrm{P}$ and $\mathrm{K}$ fertilizers: a review. J Prod Agric 1(1):70-79

Roose T, Flower A (2004) A model for water uptake by plant roots. J Theor Biol 288:155-171

Roose T, Fowler A (2004) A mathematical model for water and nutrient uptake by plant root 567 systems. J Theor Biol 288: 173-184

Roose T, Fowler A, Darrah P (2001) A mathematical model of plant nutrient uptake. Math Biol 42(4):347-360

Selmants P, Hart S (2010) Phosphorus and soil development: does the Walker and Syers model apply to semiarid ecosystems? Ecology 91(2):474-484

Sylvester-Bradley R (1991) Modelling and mechanisms for the development of agriculture. Aspects of Applied Biology 26, The Art and Craft of Modelling in Applied Biology 55-67

Sylvester-Bradley R, El L, Sparkes D, Scott RK, Wiltshire JJ, Orson JO (1999) An analysis of precision farming in Northern Europe. Soil Use Manag 15:1-9

Sylvester-Bradley R, Berry P, Blake J, Kindred D, Spink J, Bingham I, McVittie J, Foulkes J (2008) The wheat growth guide, Spring 2008, 2nd edn. HGCA, London 30pp http:// www.hgca.com/media/185687/g39-the-wheat-growth-guide. pdf. Accessed 9 Dec 2014

Tandy S, Mundus S, Yngvesson J, de Bang T, Lombi E, Schjoerring J, Husted S (2011) The use of DGT for prediction of plant available copper, zinc and phosphorus in agricultural soils. Plant Soil 346(1-2):167-180

Thornley JH (1995) Shoot: root allocation with respect to C, N and $\mathrm{P}$ : an investigation and comparison of resistance and teleonomic models. Ann Bot 75(4):391-405

Vaccari D (2009) Phosphorus: a looming crisis. Sci Am 300:54-59

Valkama E, Uusitalo R, Turtola E (2011) Yield response models to phosphorus application: a research synthesis of Finnish field trials to optimize fertilizer P use of cereals. Nutr $\mathrm{Cycl}$ Agroecosyst 91:1-15

Van Genuchten M (1980) A closed-form equation for predicting the hydraulic conductivity of unsaturated soil. Soil Sci Soc Am J 44(5):892-898

Van Rotterdam A, Temminghoff E, Schenkeveld W, Hiemstra T, Riemsdijk W (2009) Phosphorus removal from soil using Fe oxide-impregnated paper: processes and applications. Geoderma 151(3-4):282-289

Van Rotterdam A, Bussink D, Reijneveld J (2014) Improved phosphorus fertilisation based on better prediction of availability in soil. International Fertiliser Society, Proceeding 755, ISBN 978-0-85310-392-9

Vance C, Uhde-Stone C, Allan D (2003) Phosphorus acquisition and use: critical adaptations by plants for securing a nonrenewable resource. New Phytol 157:423-447

Wager BI, Stewart JWB, Henry JL (1986) Comparison of single large broadcast and small annual seed-placed phosphorus treatments on yield and phosphorus and zinc contents of wheat on Chernozemic soils. Can J Soil Sci 66:237-248

Wissuwa M, Gamat G, Ismail AM (2005) Is root growth under phosphorus deficiency affected by source or sink limitations? J Exp Bot 56(417):1943-1950

Withers PJA, Sylvester-Bradley R, Jones DL, Healey JR, Talboys PJ (2014) Feed the crop not the soil: rethinking phosphorus management in the food chain. Environ Sci Technol 48: 6523-6530

Withers PJA, van Dijk KC, Neset T-SS, Nesme T, Oenema O, Rubæk GH, Schoumans OF, Smit B, Pellerin S (2015) Stewardship to tackle global phosphorus inefficiency: the case of Europe. AMBIO 44(Suppl):S193-S206

Yang X, Post W, Thornton P, Jain A (2013) The distribution of soil phosphorus for global biogeochemical modeling. Biogeosci Discuss 9(11):16347-16380 